\title{
Impact of Loco-Regional Surgical Control on Survival of Extremity Soft Tissue Sarcoma Among Patients of Hadhramout National Cancer Center
}

\author{
Salah Ahmed Binziad ${ }^{1}$, Abdulla Saleh Alyamani ${ }^{1}$, Khalid Ahmed Baeesa ${ }^{2}$, Waleed Khaled Kaleem ${ }^{3}$, \\ Adnan Abdullah Bakarman ${ }^{4}$, Moutez Alyazedi ${ }^{5}$ \\ ${ }^{1}$ Department of Surgery, College of Medicine, Hadhramout University, Mukalla, Hadhramout, Yemen \\ ${ }^{2}$ Department of Orthopedic Surgery, College of Medicine, Hadhramout University, Mukalla, Hadhramout, Yemen \\ ${ }^{3}$ Department of Clinical Oncology, Faculty of Medicine, Hadhramout University, Mukalla, Hadhramout, Yemen \\ ${ }^{4}$ Department of Hematology, Faculty of Medicine Hadhramout University, Mukalla, Hadhramout, Yemen \\ ${ }^{5}$ Family Medicine, Faculty of Medicine, Hadhramout University, Mukalla, Hadhramout, Yemen \\ Email address: \\ binziadoncos@gmail.com (S. A. Binziad), alyamani1000@yahoo.com (A. S. Alyamani), Khalidbaeassa@gmail.com (K. A. Baeesa), \\ waleed_kaleem@yahoo.com (W. K. Kaleem), Ab_Bakarman@yahoo.com (A. A. Bakarman), mootazmohammed@gmail.com (M. Alyazedi)
}

\section{To cite this article:}

Salah Ahmed Binziad, Abdulla Saleh Alyamani, Khalid Ahmed Baeesa, Waleed Khaled Kaleem, Adnan Abdullah Bakarman, Moutez Alyazedi. Impact of Loco-Regional Surgical Control on Survival of Extremity Soft Tissue Sarcoma Among Patients of Hadhramout National Cancer Center. Advances in Surgical Sciences. Vol. 7, No. 1, 2019, pp. 15-20. doi: 10.11648/j.ass.20190701.14

Received: December 23, 2018; Accepted: January 23, 2019; Published: February 15, 2019

\begin{abstract}
Background: Loco-regional surgery remains the mainstay therapy of extremity soft tissue sarcoma (ESTS) and provides the only chance of cure. Improvements of surgical technique, increased surgical experience, radiotherapy, adjuvant and neoadjuvant chemotherapy increased the survival. Aim of study: to evaluate the effect of the type of surgical intervention on the survival and quality of life of ESTS Patients. Methods: This is a prospective study to evaluate the impact of locoregional surgical control on the survival among ESTS patients attended the National Cancer Center, Hadhramout -Yemen, between April 2010 and October 2018. Extremity soft tissue sarcoma patients were operated either by wide-local excision with safety margin or amputation or disarticulation. The study population consisted of 52 patients in which males and females represented (53.85\%) and (46.15\%) respectively. The three variable methods were compared using Chi-square test. Survival rate was analyzed by Kaplan-Meier test. Results: Fifty two patients, 12 patients in Group I (23, 1\%), 10 patients in Group II (19.2\%) and 30 patient's in Group III (57.7\%). The mean survival in patients underwent disarticulation was (77.5) months, while patients who had an amputation, the survival was (45.5) months, and in wide local resection patients was (59.9) months. The mean overall survival was (65.9) months, $\mathrm{P}$ value $<(0.026)$ which was significant. Among the 3 different types of management, high overall survival rate was found in patients underwent disarticulation, while overall survival rate was also high in patient underwent wide local excision or compartmental resection in spite of functional limb preservation and good quality of life. The mean overall survival rate was low in patients who had limb amputation with loss of limb function. Conclusion: The wide local excision or compartmental resection mandates margin-negative, accepted post-operative local wound complication, associated with prolonged disease-free-survival and overall survival than other methods. Must be deal with improve patient overall survival, decrease local recurrence and obtained best Oncological outcome by preserve function with good quality of life for ESTS patients who underwent wide or compartmental resection or radical limb sparing surgery.
\end{abstract}

Keywords: Extremity Soft Tissue Sarcoma, Overall Survival, Local Control, Outcome

\section{Introduction}

The treatment of patients with soft tissue sarcomas of the extremities has served as a model for the development of treatment strategies using adjuvant therapies to preserve function, and patient with extremity soft tissue sarcoma still 
need amputation in an era of the multimodality limb salvage or limb sparing surgery treatment for locally advanced extremity soft tissue sarcoma (ESTS).

Soft-tissue sarcoma (STS) refers to as a rare and heterogeneous group of malignant tumors comprising more than 50 histological subtypes derived from connective tissues and other cells of mesenchymal origin. Soft tissue sarcoma accounts for approximately $1 \%$ of all incident malignancies [1].

Extremity STS in particular accounts for approximately $50 \%$ of all STS. Major amputation was once a mainstay of therapy for extremity sarcoma (ES). Wardrop published the first illustration of amputation for a fungating "soft cancer" in 1809. Amputations chosen judiciously are associated with excellent disease control and survival [2-4]. Sarcomas can be grossly divided into three main kinds: soft tissue sarcoma (STS), visceral sarcoma and bone sarcoma [5].

Almost 40 years ago, surgical resection was deemed as the only therapeutic intervention for STS which in high grade tumors resulted in poorer prognosis and shorter survival rates. Good investigative techniques, higher clinical vigilance with pre and post-operative radiation and chemotherapy has helped increase long term survival and reduced morbidity in patients of these rare tumors [6]. Achieve long-term survival, although surgery remains the mainstay of therapy for primary lesions [7].

Aim of study: to evaluate the effect of the type of surgical intervention on survival and quality of life among patients with ESTS.

\section{Methods}

\subsection{Study Material}

This is a prospective study which was conducted at Hadhramout National Cancer Center-Yemen. In this analytic study all patients, between April 2010 and October 2018, with ESTS and those who underwent wide-local excision with safety margin, an amputation and disarticulation were included. Patients were grouped, according to the type of operation, into three main groups, Group I, II and III, respectively. Group I included patients underwent disarticulation, group II included those who underwent an amputation, while Group III included patients with wide local excision with safety margin or compartmental resection as primary or as non - primary treatment. Preoperative investigative studies such as computerized tomography (CT), magnetic resonance imaging (MRI) and true-cut biopsy reports were recorded. Intra-operative findings, procedure details and postoperative orders were recorded. Postoperative chemo-radiotherapy was recorded. Size and depth of the tumor and structures invaded or compressed by the tumor were assessed by radiography. Patients were consented after full discussion of the procedure and there needs for adjuvant radiotherapy or chemotherapy and follow up were preoperatively discussed with them.

Those patients having malignant tumors size more than
$10 \mathrm{~cm}$ and those that cannot get free surgical margins due to size, were referred to the oncologist to receive preoperative down staging chemo and/or radiotherapy to down stage the tumor.

The follow up records were accessed from the outpatient department and any surgical complications were recorded up to 1 year.

Staging was done using clinical and radiological criteria taking into account the histopathological staging in follow up and their impact on ESTS patients survival. The need for a particular surgical procedure was determined according to clinical findings and radiological evaluation. Inoperable cases and tumors with clearly benign clinical and histological findings were excluded

We directly evaluated impacts of quality of surgical interventions (disarticulation, an amputation and wide local excision with safety margin or compartmental radical resection) on survival and quality of life of ESTS patients.

\subsection{Statistical Analyses}

Variables and frequency counts and percentages for categorical variables were computed. Overall survival from advanced ESTS diagnosis was measured using the death information available from Hadhramout National cancer Registry-Yemen and survival time end points were analyzed using the Kaplan Meier estimates with mean survival time and $95 \%$ confidence intervals (CIs) i.e., means, medians, and standard deviations (SDs) of continuous reported in months. Patients alive at the end of study period were censored for this analysis.

Surgical patterns and survival were assessed in the overall advanced ESTS population and by histological category. We used SPSS version 22 and managed my references by Mendeley Desktop version 1.19.3 C2008-2018 Mendeley, Ltd. All rights reserved.

\section{Results}

Fifty two patients, males $(53.85 \%)$ and females $(46.15 \%)$ were included, Figure 1. 12 patients in Group I (23.1\%), 10 patients in Group II (19.2\%) and 30 patients in Group III (57.7\%). Table 1. Type of histopathology was recorded on Figure 2. Tumor size or local recurrence were the two main reasons for an amputation or disarticulation.

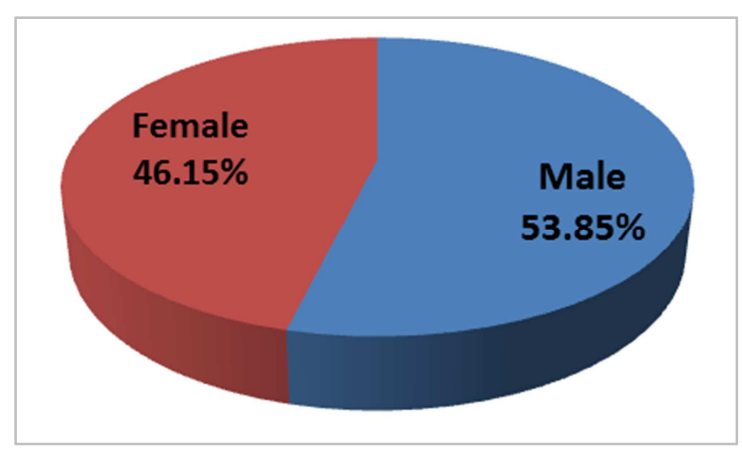

Figure 1. Gender Distribution. 


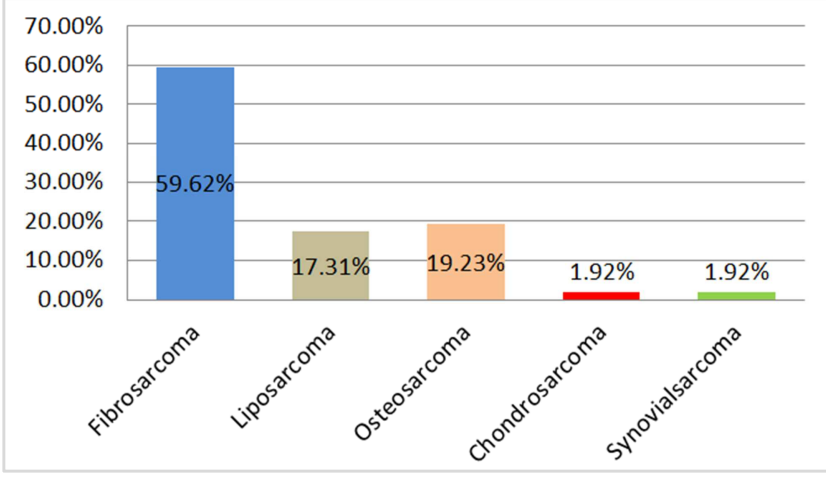

Figure 2. Tumor histological subtypes and their frequencies.

Postoperative complications were: Wound infection 3 $(6.25 \%)$, Subcutaneous Seroma1 (2\%), Bleeding / Hematoma $(0 \%)$, Wound Dehiscence $2(4.1 \%)$ and Flap necrosis 4 $(8.3 \%)$.

Table 1. Type of Surgical Interventions.

\begin{tabular}{llll}
\hline & Frequency & Percent \\
\hline \multirow{3}{*}{ Valid } & Disarticulation limp & 12 & $23.1 \%$ \\
& Amputation & 10 & $19.2 \%$ \\
& wide local resection & 30 & $57.7 \%$ \\
& Total & 52 & 100.0 \\
\hline
\end{tabular}

In this study 12 patients (23.1\%) underwent disarticulation. Three and 2 patients had tumor at thigh and mid arm respectively, and size was more than $10 \mathrm{~cm}$. three patients did have amputation above elbow, whereas disarticulation from shoulder joint was performed for patients who had recurrence. Four patients had an amputation above knee, but after recurrence, we did disarticulation from Hip joint. Ten patients underwent amputation 8 patients above knee and 2 patients above elbow. Thirty patients underwent wide local excision and compartmental resection with free surgical margin (see Table 1).

Local tumor recurrence was found in 7 patients $(13.5 \%)$ and distant metastasis in 3 patients $(6 \%)$ (see Table 2$)$.

Table 2. Local Tumor Recurrence\& Distant Mets.

\begin{tabular}{lll}
\hline & Frequency & Percent \\
\hline No Tumor Recurrence & 42 & $80.8 \%$ \\
Local Recurrence & 7 & $13.5 \%$ \\
Distant mets & 3 & $6 \%$ \\
Total & 52 & 100.0 \\
\hline
\end{tabular}

We evaluated the types of surgical procedures in the study by Chi-Square and their impact on survival of ESTS patients, we found that 12 patient with disarticulation, two patients died, 10 patients with amputation, 5 of which were dead and 30 patients with wide local excision, with 5 dead patients (Table 3).

Table 3. Case Processing Summary.

\begin{tabular}{lllll}
\hline \multirow{2}{*}{ Intervention } & Total N & N of Events & \multicolumn{2}{l}{ Censored } \\
\cline { 5 - 5 } & & & $\mathbf{N}$ & Percent \\
\hline Disarticulation limb & 12 & 2 & 10 & $83.3 \%$ \\
Amputation & 10 & 5 & 5 & $50.0 \%$ \\
Wide local resection & 30 & 5 & 25 & $83.3 \%$ \\
Overall & 52 & 12 & 40 & $76.9 \%$ \\
\hline
\end{tabular}

There is statistical significant $\mathrm{P}$ value $(0.026)$, the mean overall survival was (65.9) months. The mean survival time in disarticulation patients was (77.5) months, while in an amputated patients was (45.5) months, and finally in wide local resection and compartmental resection patients was (59.9) months (Table 4, 5) and (Figure 3), still 40 patients were censored and will be followed.

Table 4. Means and Medians for Survival Time.

\begin{tabular}{|c|c|c|c|c|c|c|c|c|}
\hline \multirow{3}{*}{ Intervention } & \multicolumn{4}{|l|}{ Mean $^{a}$} & \multicolumn{4}{|l|}{ Median } \\
\hline & \multirow{2}{*}{ Estimate } & \multirow{2}{*}{ Std. Error } & \multicolumn{2}{|c|}{ 95\% Confidence Interval } & \multirow{2}{*}{ Estimate } & \multirow{2}{*}{ Std. Error } & \multicolumn{2}{|c|}{ 95\% Confidence Interval } \\
\hline & & & Lower Bound & Upper Bound & & & Lower Bound & Upper Bound \\
\hline Disarticulation limp & 77.500 & .500 & 76.520 & 78.480 & 77.000 & . & . & . \\
\hline Amputation & 45.958 & 5.703 & 34.781 & 57.136 & 42.000 & 4.793 & 32.606 & 51.394 \\
\hline wide local resection & 59.956 & 3.588 & 52.925 & 66.988 & . & . & . & . \\
\hline Overall & 65.988 & 3.360 & 59.403 & 72.573 & 77.000 & 20.709 & 36.411 & 117.589 \\
\hline
\end{tabular}

Table 5. Tests Comparisons of survival distributions for the different levels of Intervention.

\begin{tabular}{llll}
\hline & Chi-Square & df & Sig. \\
\hline Log Rank (Mantel-Cox) & 8.449 & 2 & .015 \\
Breslow (Generalized Wilcoxon) & 7.290 & 2 & .026 \\
Tarone-Ware & 8.052 & 2 & .018 \\
\hline
\end{tabular}




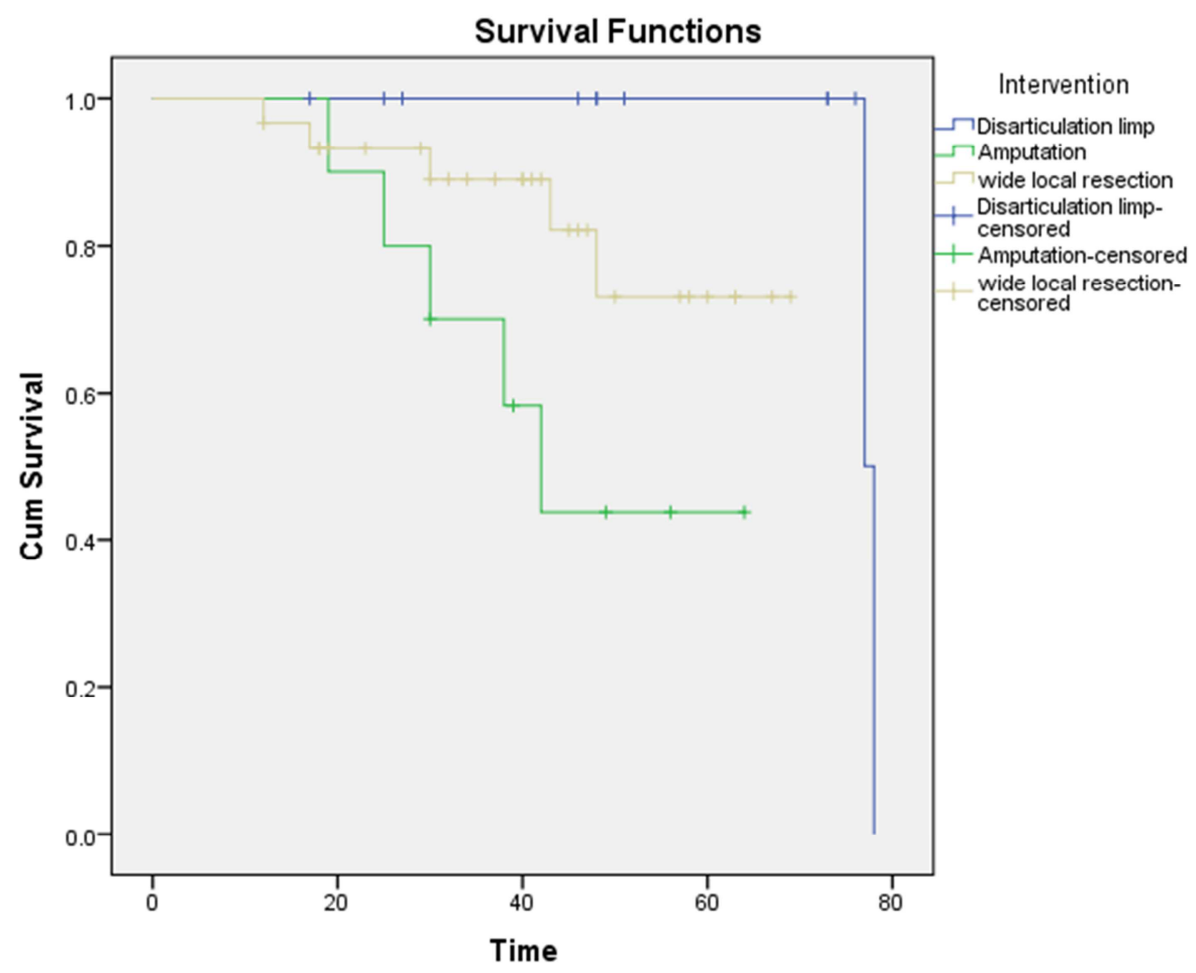

Figure 3. Survival Function.

Overall survival on 12 disarticulation patient was minimum 17 months, maximum 79 months, overall survival in 10 patients who underwent amputation was minimum 19 months, maximum 65 months, and in 30 patients underwent wide local excision and compartmental resection was minimum 12 months, maximum 69 months and, (Table 6).

Table 6. Survival Rate.

\begin{tabular}{|c|c|c|c|c|c|c|c|}
\hline \multirow{2}{*}{ Intervention } & \multirow{2}{*}{ ID } & \multirow{2}{*}{ Time } & \multirow{2}{*}{ Status } & \multicolumn{2}{|c|}{ Cumulative Proportion Surviving at the Time } & \multirow{2}{*}{$\begin{array}{l}\mathrm{N} \text { of Remaining } \\
\text { Cases }\end{array}$} & \multirow{2}{*}{$\begin{array}{l}\mathrm{N} \text { of Cumulative } \\
\text { Events }\end{array}$} \\
\hline & & & & Std. Error & Estimate & & \\
\hline \multirow{12}{*}{ Disarticulation Lip } & 41 & 17 & Censored & . & . & 0 & 11 \\
\hline & 32 & 25 & Censored & . & . & 0 & 10 \\
\hline & 14 & 27 & Censored & . & . & 0 & 9 \\
\hline & 19 & 46 & Censored & . & . & 0 & 8 \\
\hline & 2 & 48 & Censored & . & . & 0 & 7 \\
\hline & 3 & 48 & Censored & . & . & 0 & 6 \\
\hline & 4 & 51 & Censored & . & . & 0 & 5 \\
\hline & 43 & 73 & Censored & . & . & 0 & 4 \\
\hline & 47 & 73 & Censored & . & . & 0 & 3 \\
\hline & 48 & 76 & Censored & . & . & 0 & 2 \\
\hline & 44 & 77 & Died & 0.5 & 0.354 & 1 & 1 \\
\hline & 46 & 78 & Died & 0 & 0 & 2 & 0 \\
\hline \multirow{10}{*}{ Amputation } & 42 & 19 & Died & 0.9 & 0.095 & 1 & 9 \\
\hline & 15 & 25 & Died & 0.8 & 0.126 & 2 & 8 \\
\hline & 35 & 30 & Died & 0.7 & 0.145 & 3 & 7 \\
\hline & 13 & 30 & Censored & . & . & 3 & 6 \\
\hline & 28 & 38 & Died & 0.583 & 0.161 & 4 & 5 \\
\hline & 22 & 39 & Censored & . & . & 4 & 4 \\
\hline & 27 & 42 & Died & 0.438 & 0.175 & 5 & 3 \\
\hline & 9 & 49 & Censored & . & . & 5 & 2 \\
\hline & 45 & 56 & Censored & . & . & 5 & 1 \\
\hline & 8 & 64 & Censored & . & . & 5 & 0 \\
\hline \multirow{4}{*}{$\begin{array}{l}\text { wide local resection \& } \\
\text { Compartmental } \\
\text { Resection }\end{array}$} & 39 & 12 & Died & 0.967 & 0.033 & 1 & 29 \\
\hline & 52 & 12 & Censored & . & . & 1 & 28 \\
\hline & 17 & 17 & Died & 0.932 & 0.046 & 2 & 27 \\
\hline & 38 & 18 & Censored & & . & 2 & 26 \\
\hline
\end{tabular}




\begin{tabular}{|c|c|c|c|c|c|c|c|}
\hline \multirow{21}{*}{ Intervention } & \multirow{2}{*}{ ID } & \multirow{2}{*}{ Time } & \multirow{2}{*}{ Status } & \multicolumn{2}{|c|}{ Cumulative Proportion Surviving at the Time } & \multirow{2}{*}{$\begin{array}{l}\mathrm{N} \text { of Remaining } \\
\text { Cases }\end{array}$} & \multirow{2}{*}{$\begin{array}{l}\mathrm{N} \text { of Cumulative } \\
\text { Events }\end{array}$} \\
\hline & & & & Std. Error & Estimate & & \\
\hline & 40 & 18 & Censored & . & . & 2 & 25 \\
\hline & 37 & 19 & Censored & . & . & 2 & 24 \\
\hline & 34 & 23 & Censored & . & . & 2 & 23 \\
\hline & 33 & 29 & Censored & . & . & 2 & 22 \\
\hline & 7 & 30 & Died & 0.89 & 0.061 & 3 & 21 \\
\hline & 29 & 30 & Censored & . & . & 3 & 20 \\
\hline & 31 & 32 & Censored & . & . & 3 & 19 \\
\hline & 30 & 34 & Censored & . & . & 3 & 18 \\
\hline & 26 & 37 & Censored & . & . & 3 & 17 \\
\hline & 23 & 40 & Censored & . & . & 3 & 16 \\
\hline & 50 & 40 & Censored & . & . & 3 & 15 \\
\hline & 25 & 41 & Censored & . & . & 3 & 14 \\
\hline & 20 & 42 & Censored & . & . & 3 & 13 \\
\hline & 24 & 43 & Died & 0.821 & 0.086 & 4 & 12 \\
\hline & 10 & 45 & Censored & . & . & 4 & 11 \\
\hline & 36 & 46 & Censored & . & . & 4 & 10 \\
\hline & 21 & 47 & Censored & . & . & 4 & 9 \\
\hline & 5 & 48 & Died & 0.73 & 0.115 & 5 & 8 \\
\hline & 1 & 50 & Censored & . & . & 5 & 7 \\
\hline
\end{tabular}

Table 6. Continue.

\begin{tabular}{|c|c|c|c|c|c|c|c|}
\hline \multirow{2}{*}{ Intervention } & \multirow{2}{*}{ ID } & \multirow{2}{*}{ Time } & \multirow{2}{*}{ Status } & \multicolumn{2}{|c|}{ Cumulative Proportion Surviving at the Time } & \multirow{2}{*}{$\begin{array}{l}\mathrm{N} \text { of Remaining } \\
\text { Cases }\end{array}$} & \multirow{2}{*}{$\begin{array}{l}\mathrm{N} \text { of Cumulative } \\
\text { Events }\end{array}$} \\
\hline & & & & Std. Error & Estimate & & \\
\hline \multirow{7}{*}{$\begin{array}{l}\text { wide local } \\
\text { resection \& } \\
\text { Compartmental } \\
\text { Resection }\end{array}$} & 18 & 57 & Censored & (1) & . & 5 & 6 \\
\hline & 16 & 58 & Censored & . & . & 5 & 5 \\
\hline & 11 & 60 & Censored & . & . & 5 & 4 \\
\hline & 49 & 63 & Censored & . & . & 5 & 3 \\
\hline & 51 & 63 & Censored & . & . & 5 & 2 \\
\hline & 6 & 67 & Censored & . & . & 5 & 1 \\
\hline & 12 & 69 & Censored & . & . & 5 & 0 \\
\hline
\end{tabular}

\section{Discussion}

The heterogeneity of sarcomas with regard to molecular genesis, histology, clinical characteristics, and response to treatment makes management of these rare yet diverse neoplasms particularly challenging [8]. Surgical resection remains the cornerstone of therapy for localized disease and achieves a five-year overall survival around $75 \%$ and a local recurrence rate as low as $10 \%$ in the best series [9].

The quality of surgery directly impacts the final prognosis of ESTS patients [10]. En-bloc wide soft part resection (158 cases) yielded five and ten year survival rates of $63 \%$ and $50 \%$. Amputation or major disarticulation (139 cases) gave corresponding survival rates of $45 \%$ and $29 \%$ [11]. In the era of multimodality therapy, radical resection of extremity tumors has been replaced by conservative surgical techniques that aim to preserve limb function. An example of this paradigm shift is seen with the management of soft-tissue sarcomas of the extremities. Thirty years ago, amputation was the primary treatment for nearly $50 \%$ of extremity sarcomas [12].

In our study male patients more than female patients with mean age of 42.3 years \pm 16.633 , while malignant fibrosarcoma was the predominant subtype of tumor encountered (59.62\%). While we used Kaplan-Meier curves to illustrate the impact of surgical intervention on survival patterns observed in our patient population, the result was statically and clinical significant with $P$ value (0.026). We found the mean overall survival in patients with limb disarticulation in 12 patients was (77.5) months, compared with (59.9) months was the mean overall survival of 30 patients underwent wide-local excision and compartmental resection, while the mean overall survival was (45.9) months in 10 amputated patients. We found The quality of life and function preservation was better in patient underwent compartmental resection and wide local excision than patients underwent amputation and disarticulation and in comparable the impact of overall survival among 3 types of surgical interventions, we found that disarticulation and wide local excision give best overall survival rate than amputation. In Henry G. et al, study the Three-year overall survival (OS) was $50.3 \%$ following curative amputation, with a median survival of 41 months, and median OS following palliative amputation was 6 months. The rates of systemic relapse and disease-specific survival were poorer following amputation compared with limb-conserving surgery, however mode of surgery (amputation vs. limb conservation) was only prognostic for OS [13].

Wide or radical limb-sparing, function-preserving surgery with negative margins is the standard of care for ESTS. Amputation is occasionally the only option (poor function, fungating tumor, fracture, field defect, neurovascular compromise), but given the similar OS rates 
after limb-sparing plus external beam radiation therapy (EBRT) versus amputation, it should not be considered routinely [14].

\section{Conclusions}

In summary must deal with improve patient overall survival, decrease local recurrence and obtained best oncological outcome and preserve function with good quality of life for ESTS patients who underwent wide or compartmental resection or radical limb sparing. An amputation must be limited for large tumor size, neural invasion. Select proper interventions need to be decided in a multidisciplinary sarcoma team meeting which treatment suits best for each individual patient.

\section{References}

[1] Ferrone ML, Raut CP. Modern Surgical Therapy: Limb Salvage and the Role of Amputation for Extremity Soft-Tissue Sarcomas. Surg Oncol Clin N Am. 2012; 21 (2): 201-213. doi:10.1016/j.soc.2011.11.001.

[2] Brennan M, Alektiar KM, Maki RG. Soft tissue sarcoma. In: DeVita VT, Hellmann S, Rosenberg SA, editors. Cancer: principles and practice of oncology, $6^{\text {th }}$ ed. Philadelphia: Lippincott Williams \& Wilkins, 2001: 1844-1891.

[3] Wardrop J. Observations on fungus haematodes or soft cancer. Edinburgh: G Ramsay; 1809.

[4] Erstad D, Ready J, Abraham J, et. Al. Amputation for Extremity Sarcoma: Contemporary Indications and Outcomes. Annals of Surgical Oncology. 2018 vol: 25 (2) pp: 394-403. Doi; 10.1245/s10434-017-6240-5.

[5] Fletcher C, Bridge JA Hogendoorn P, Mertens F (eds) (2013) WHO Classification of tumours of soft tissue and bone, $4^{\text {th }}$ edn. IARC Press, Lyon.
[6] Smith HG, Thomas JM, Smith MJF, Hayes AJ, Strauss DC. Major Amputations for Extremity Soft-Tissue Sarcoma. Ann SurgOncol. 2018; 25 (2): 387-393. doi:10.1245/s10434-0175895-2.

[7] Shiu MH, Castro EB, Hajdu SI, Fortner JG. Surgical treatment of 297 soft tissue sarcomas of the lower extremity. Ann Surg. 1975; 182 (5): 597-602. doi:10.1097/00000658-19751100000011 .

[8] Parsons CM, Pimiento JM, Cheong D, et al. The role of radical amputations for extremity tumors: A single institution experience and review of the literature. J SurgOncol. 2012; 105 (2): 149-155. doi:10.1002/jso.22067.

[9] Yang JC, Chang AE, Baker AR, et al. Randomized prospective study of the benefit of adjuvant radiation therapy in the treatment of soft tissue sarcomas of the extremity. J Clin Oncol. 1998; 16 (1):197-203. doi:10.1200/JCO.1998.16.1.197.

[10] Dancsok AR, Asleh-Aburaya K, Nielsen TO. Advances in sarcoma diagnostics and treatment. Oncotarget. 2017; 8 (4). doi:10.18632/oncotarget.12548.

[11] Wibmer C, Leithner A, Zielonke N, Sperl M WR. Increasing incidence rates of soft tissue sarcomas? A population-based epidemiologic study and literature review. 1. Ann Onco. 2010; 21 (1): 1106-1111.

[12] Khan MM, 1, Waqar SH, et al. Surgical Management of Soft Tissue Sarcoma. J Rawalpindi Med Coll (JRMC. 2018; 22 (1): 58-62.

[13] Bonvalot S, Rimareix F, Paumier A, Roberti E, Bouzaiene H, Le Péchoux C. Actualisation de la stratégie thérapeutique locorégionale dans les sarcomes des tissusmous et les tumeursdesmoïdes des membres. Cancer/Radiothérapie. 2010; 14 (6-7): 455-459. doi:10.1016/j.canrad.2010.06.016.

[14] Parikh RC, Lorenzo M, Hess LM, Candrilli SD, Nicol S, Kaye JA. Treatment patterns and survival among older adults in the United States with advanced soft-tissue sarcomas. Clin Sarcoma Res. 2018; 8 (1): 8. doi:10.1186/s13569-018-0094-x. 